\title{
Isolation of Essential Oils from Essential Roots (Vetiveria zizanoides L.) with Preparation Using Liquid Nitrogen
}

\section{Isolasi Minyak Atsiri dari Akar Wangi (Vetiveria zizanoides L.) dengan Preparasi Menggunakan Nitrogen Cair}

\author{
A. Ashari ${ }^{1,2 *}, \&$ Ciptati $^{2}$ \\ 1) Department of Chemistry, Institut Teknologi Sumatera \\ 2) Labratorium Kimia Organik, Institut Teknologi Bandung \\ *Corresponding author: arifashari1009@gmail.com
}

\begin{abstract}
Fragrant root oil production can be done by various methods including distillation, pressing, extraction using solvents and extraction using solid fat. Efforts to increase the production of quality fragrant root oil before the extraction process carried out 2 treatments on the sample, namely chopping and preparation using liquid nitrogen. Research that has been carried out sample preparation using $\mathrm{N}_{2}$ (1) has proven to be effective in increasing oil yield. In fresh samples, the yield of oil obtained from the steam-hydro distillation method is $0.84 \%$ (variation 1) and $1.2 \%$ (variation 2) while for the socletation method is $1 \%$ (variation 1) and $2.4 \%$ ( variation 2). From the results of GC-MS analysis, the fragrant root oil of the dry sample was identified as composed of 68 components and there were 2 components that were suspected as oil fingerprints namely khusimene (4.44\%) and nootkatone (2.02\%)
\end{abstract}

Kata kunci: minyak atsiri, steam-hydro distillation, GC-MS analysis

\section{PENDAHULUAN}

Minyak atsiri atau minyak esensial (essential oil) adalah komoditi ekstrak alami dari jenis tumbuhan yang berasal dari akar, daun, bunga, kayu, biji-bijian bahkan putik bunga. Keanekaragaman hayati yang dimiliki Indonesia menjadikan Indonesia merupakan salah satu negara penghasil minyak atsiri terbesar di dunia. Salah satu jenis minyak atsiri yang banyak diproduksi di Indonesia adalah yang berasal dari tanaman akar wangi atau minyak akar wangi (vetiver oil). Minyak akar wangi merupakan cairan kental, berwarna kuning kecoklatan hingga coklat gelap, memiliki aroma sweet, earthy, dan woody (Martinez dkk., 2004). Minyak akar wangi sering digunakan sebagai pengikat aroma (fixative agent) dalam industri parfum dan kosmetik.

Sentra budidaya tanaman dan produksi minyak akar wangi di Indonesia berada di 
Kabupaten Garut, Jawa Barat. Produksi minyak akar wangi sebagian besar dilakukan oleh industri kecil dengan menggunakan teknologi sederhana atau konvensional sehingga minyak akar wangi produksi Indonesia memiliki rendemen serta kualitas yang masih rendah dibandingkan negara penghasil lain.

Produksi minyak akar wangi dapat dilakukan dengan berbagai metode diantaranya distilasi (penyulingan), pengepresan (pressing) (Ketaren 1985), ekstraksi menggunakan pelarut dan ekstraksi menggunakan lemak padat. upaya untuk meningkatkan produksi minyak akar wangi yang berkualitas sebelum proses ekstraksi dilakukan 2 perlakuan pada sampel yaitu perajangan dan preparasi menggunakan nitrogen cair.

\section{METODOLOGI}

\section{Bahan}

Bahan yang digunakan dalam penelitian ini berupa bahan baku utama dan bahan pembantu. Bahan baku utama yang digunakan adalah akar wangi (Vetiveria zizanioides Stapt) yang berasal dari perkebunan akar wangi rakyat di daerah Garut, Jawa Barat. Bahan pembantu adalah bahan kimia yang digunakan untuk proses ekstraksi, pengujian sifat fisika dan kimia dari minyak akar wangi. Bahan kimia ini terdiri dari n-heksana teknis, etil asetat teknis, etanol teknis, $\mathrm{KOH}$, fenolftalein, $\mathrm{HCL}$, asam asetat anhidrit, natrium asetat anhidrat, akuades, natrium klorida, natrium sulfat anhidrad dan asam oksalat.

\section{Alat}

Peralatan yang digunakan dalam penelitian ini adalah seperangkat alat distilasi pelarut, rotary evaporator, gelas beker $250 \mathrm{ml}$ (pyrex), gelas ukur $5 \mathrm{ml}, 10 \mathrm{ml}$ dan $50 \mathrm{ml}$ (pyrex), erlenmeyer $25 \mathrm{ml}$ selang air, waterpump, statif dan klem, GC-MS QP2010SSHIMADZHU, timbangan elektrik (Analytical Balance Denver Instrument), corong pisah $125 \mathrm{ml}$, buret $25 \mathrm{ml}$, hot plate-stirer (IKALabortechnick), cawan petri, botol duran dan spatula logam.

\section{Prosedur}

\section{Perlakuan Awal Sampel}

Akar wangi mula-mula dipisahkan dari bonggol kemudian dibersihkan dan dikeringkan. Akar wangi yang sudah bersih dipotong kecil-kecil (dirajang) (sampel variasi 1). Akar yang telah dirajang dan direndam dengan nitrogen cair dan sampel akar digerus menjadi serbuk (variasi 2)

\section{Sokletasi}

Sampel akar sebanyak 50 gram dilakukan ekstraksi dengan metode sokletasi dengan pelarut n-hekasana selama 6 jam. Filtrat hasil sokletasi kemudian dievaporasi untuk menghilangkan pelarut sehingga diperoleh minyak akar wangi (vetiver oil).

\section{Analisa GC-Fid dan Gas Chromatography - Mass Spectrometry (GC-Ms)}

Analisa yang dilakukan untuk mengetahui komponen minyak dalam penelitian ini adalah analisa GC-FID dan GC-MS (Gas Chromatography - Mass Spectrometry). Analisa GC-FID dilakukan di Laboratorium Kimia Anorganik FMIPA ITB dan analisa GC-MS dilakukan di Laboratorium Instrumen Universitas Pendidikan Indonesia Bandung.

\section{HASIL DAN PEMBAHASAN}

Sampel akar wangi mula-mula dipisahkan dari bonggol kemudian dibersihkan dan dikeringkan. Akar wangi yang sudah bersih dan kering kemudian dipotong kecil-kecil (dirajang) yang bertujuan untuk mengurangi sifat kamba akar dan mempermudah keluarnya minyak dari dalam akar melalui proses difusi. Selanjutnya dilakukan penimbangan pada sampel.

\section{Penggunaan Nitrogen Cair sebagai Shock Temperature}

Akar wangi yang sudah dipotong kecil-kecil ditampung di dalam panci alumuniun. Kemudian dilakukan perendaman dengan nitrogen cair dan seketika itu sampel akar wangi digerus sampai menjadi serbuk. Penggunaan nitrogen cair bertujuan agar membran sel akar wangi dapat pecah atau mengalami lisis dengan adanya shock temperature dari nitrogen cair sehingga diharapkan proses ekstraksi minyak dapat lebih maksimal. Perlakuan akar wangi dengan nitrogen cair dapat dilihat pada Gambar 1. 


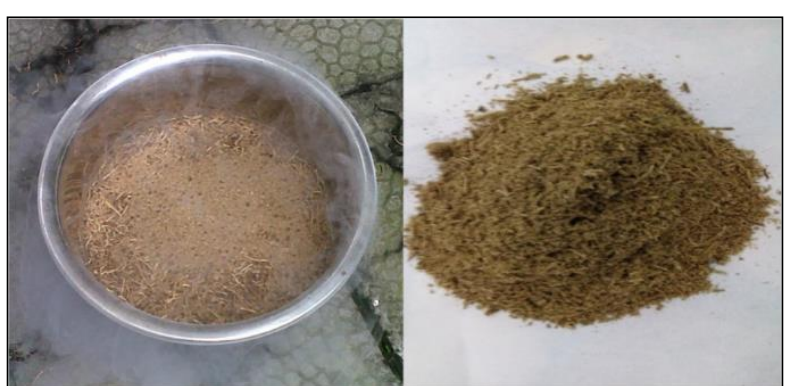

Gambar 1. Perlakuan akar wangi dengan nitrogen cair

\section{Sokletasi}

Sebanyak 50 gram sampel akar yang masih segar dari masing-masing variasi dilakukan sokletasi dengan pelarut n-heksana sebanyak $600 \mathrm{ml}$ selama 6 jam sehingga diperoleh filtrat. Pemilihan n-heksana sebagai pelarut dikarenakan minyak bersifat nonpolar sehingga untuk mengekstraksi digunakan pelarut yang non polar berdasarkan prinsip ekstraksi like dissolve like. Alat sokletasi dapat dilihat pada Gambar 2.

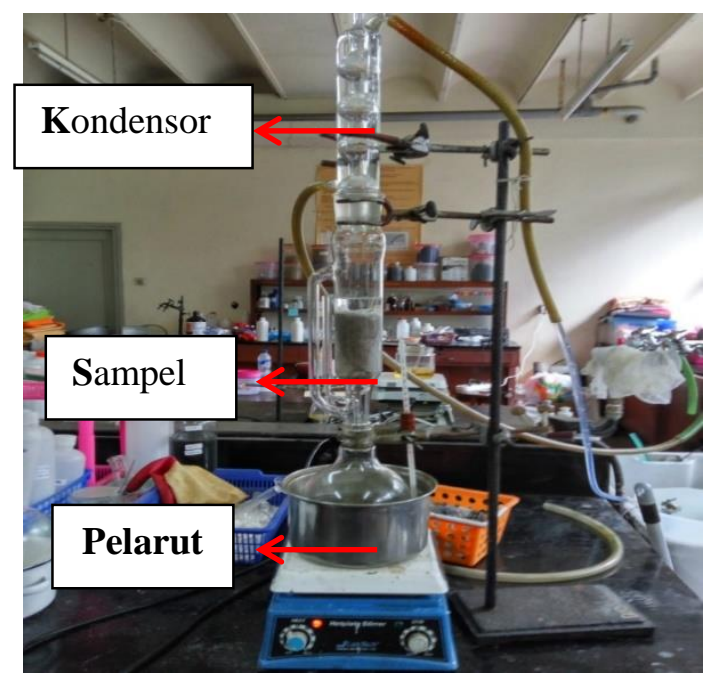

Gambar 2. Alat Sokletasi
Selanjutnya pada filtrat hasil sokletasi dilakukan evaporasi untuk menguapkan pelarut n-heksana sehingga diperoleh minyak. Rotary evaporator. Pada metode sokletasi, hasil minyak akar wangi yang diperoleh untuk sampel variasi 1 (tanpa $\mathrm{N}_{2}$ (liquid)) sebanyak $1 \mathrm{ml}$ dan untuk sampel variasi 2 (dengan $\mathrm{N}_{2 \text { (liquid) }}$ ) sebanyak 2,4 ml. Dari hasil ini terbukti bahwasannya preparasi sampel menggunakan nitrogen cair sebagai shock temperature dapat lebih memaksimalkan proses ekstraksi pada minyak akar wangi.

\section{Analisis GC-FID Minyak Akar Aangi}

Analisis GC-FID yang bertujuan untuk mengidentifikasi komponen-komponen penyusun minyak akar wangi. Analisis GC-FID dilakukan pada masing-masing variasi sampel baik metode steam-hydro distillation maupun sokletasi. Kromatogram hasil analisis GC-FID minyak skala laboratorium dapat dilihat pada Gambar 3.

Dari hasil analisis GC-FID minyak akar wangi sampel segar dengan metode sokletasi pada Gambar IV.13, minyak akar wangi sampel variasi 1 teridentifikasi terdapat 16 komponen senyawa penyusun minyak dan minyak akar wangi sampel variasi 2 terdapat 25 komponen senyawa penyusun minyak. Komponen mayor minyak sampel variasi 1 yang terdeteksi pada waktu retensi $28,480 \quad(4,30 \%)$ diduga sama dengan komponen mayor minyak sampel variasi 2 pada waktu retensi 28,67 (3,94\%). Dan komponen mayor minyak sampel variasi 1 yang terdeteksi pada waktu retensi 29,038 (2,86\%) diduga sama dengan komponen minyak sampel variasi 2 pada waktu retensi 29,22 (3,94\%). 


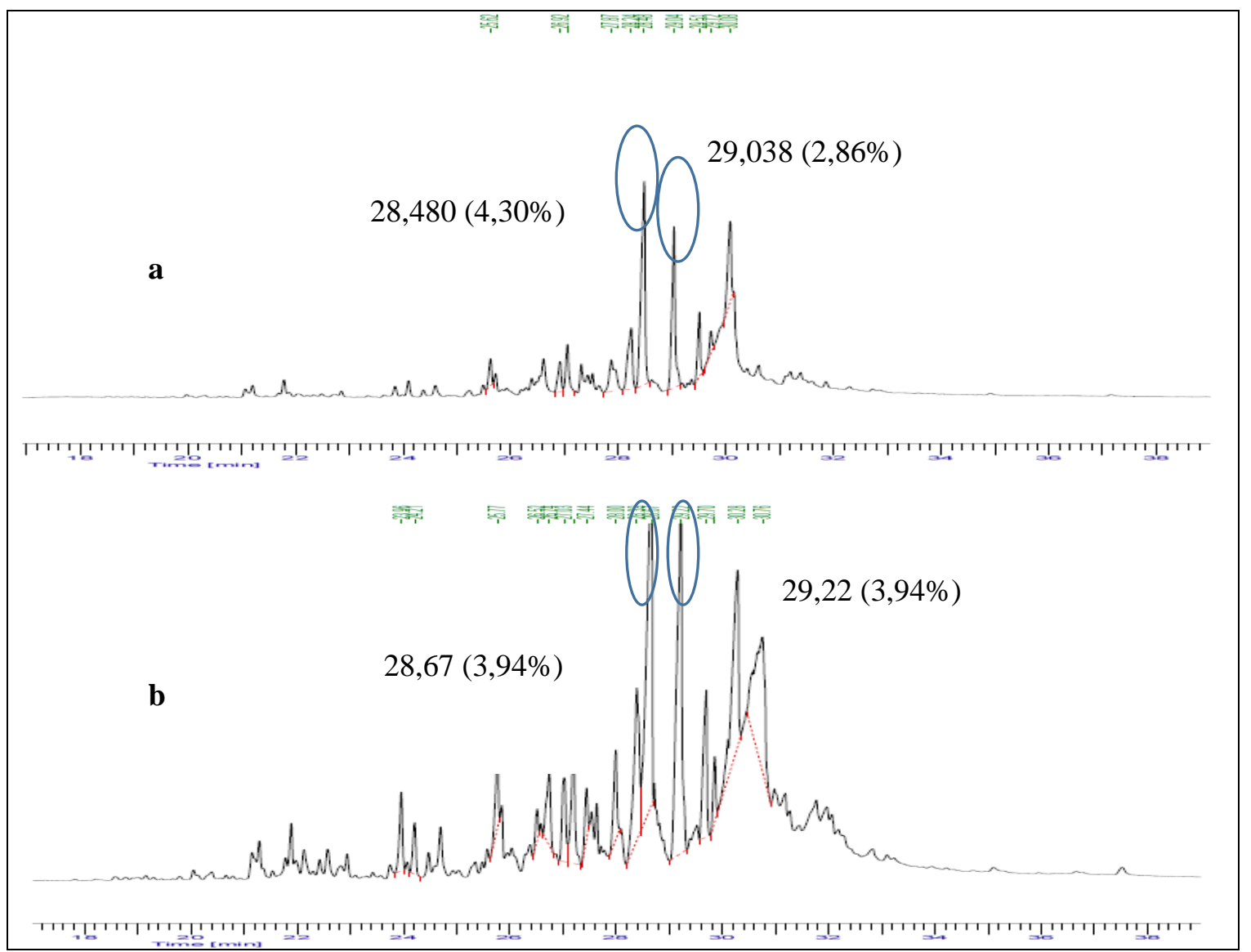

Gambar 3 Hasil analisis GC-FID minyak akar wangi metode sokletasi sampel segar (a) variasi 1 dan

(b) variasi 2

Analisis GC-MS pada minyak akar wangi hasil penelitian teridentifikasi terdapat 68 komponen senyawa penyusun minyak untuk sampel kering dan 44 komponen senyawa

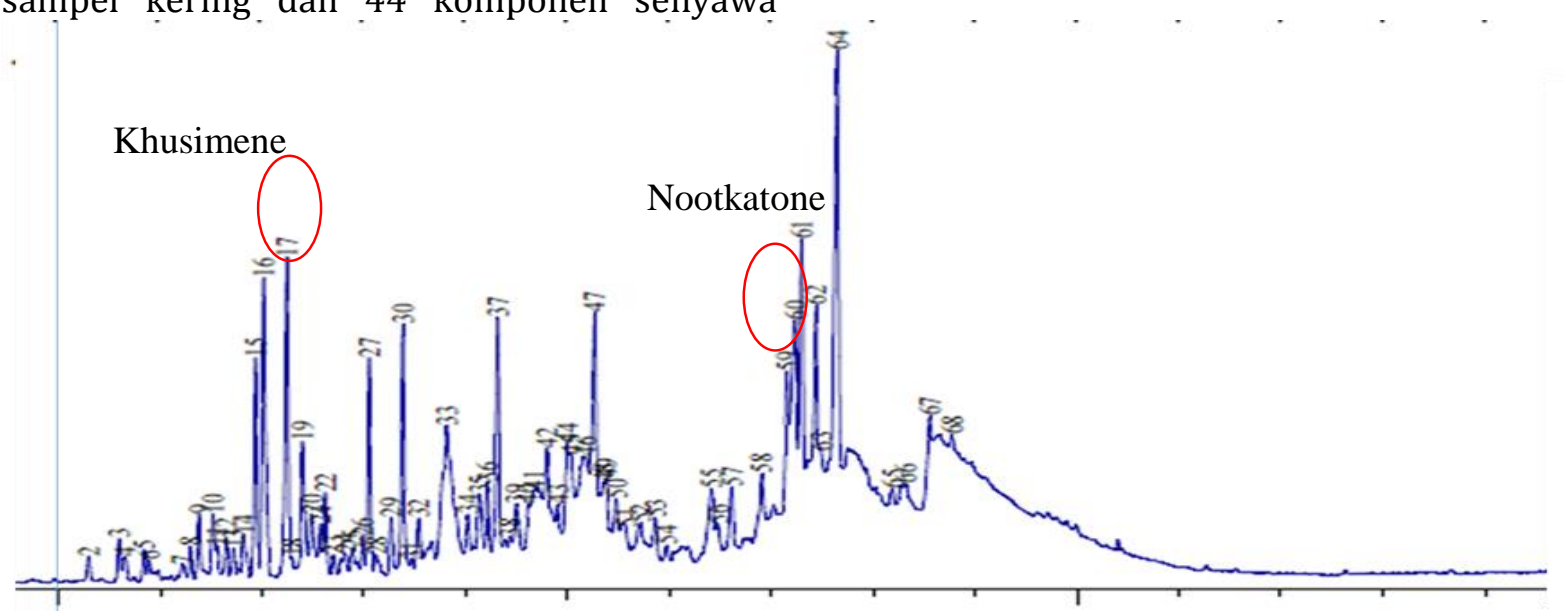

Gambar 4. Hasil analisis GC-MS minyak akar wangi.

Identifikasi komponen minyak akar wangi hasil GC-MS ini berdasarkan pendugaan dengan menggunakan referensi data base WILEY275. Berdasarkan spektrum massa komponen- penyusun minyak untuk sampel segar. Hasil analisisi GC-MS minyak akar wangi segar dapat dilihat pada Gambar 4. 
Sesquiterpen keton nootkatone merupakan isomer dari $\alpha$-vetivone yang merupakan komponen penting dari vetiver oil.
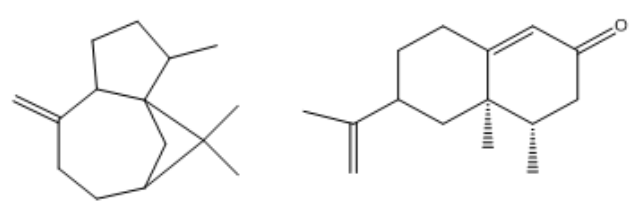

Khusimene

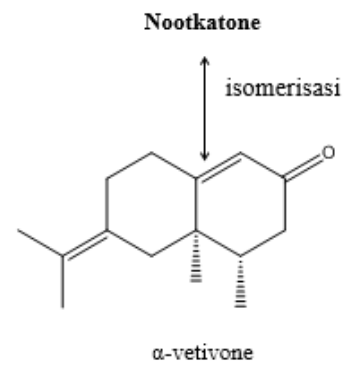

Gambar 5. Komponen sidik jari minyak akar wangi hasil penelitian

\section{KESIMPULAN}

Berdasarkan penelitian yang telah dilakukan preparasi sampel menggunakan $\mathrm{N}_{2(l)}$ terbukti efektif dalam meningkatkan rendemen minyak. Pada sampel segar, hasil rendemen minyak yang diperoleh dari metode steam-hydro distillation adalah $0,84 \%$ (variasi 1 ) dan 1,2\% (variasi 2) sedangkan untuk metode sokletasi adalah 1\% (variasi 1) dan 2,4\% (variasi 2). Dari hasil analisis $G C-M S$, minyak akar wangi sampel kering diidentifikasi tersususun atas 68 komponen dan terdapat 2 komponen yang diduga sebagai sidik jari minyak yaitu khusimene $(4,44 \%)$ dan nootkatone $(2,02 \%)$

\section{REFERENSI}

Guenther, E.,(2006) : Minyak Atsiri Jilid 1, penerjemah Ketaren S, Penerbit UI Press, Jakarta.

Guenther. (1990) : Minyak Atsiri Jilid I dan IVA, penerjemah Ketaren $S$,

Universitas Indonesia Press. Jakarta.

Hanief, M. M., Mushawwir, H. A., dan Mahfud. (2013) : Ekstraksi Minyak Atsiri dari Akar Wangi Menggunakan Metode Steam-Hydro distillation dan Hydro distilation dengan Pemanas Microwave. Jurnal teknik Pomits, 2, 219-223.
[ISO] International Organization for Standardization 4716, (2010) : Oil of vetiver

(Vetiveria zizanioides (Linnaeus) Nash), http://www.iso.org/iso/iso_

catalogue/catalogue_tc/catalogue_detail.htm?c snumber $=28587$.

Jiao, J., Fu, Y.J., Zu, Y.G., Lue, M., Wang, W., Zhang, L., dan Li, J. (2012) : Enzyme-Assisted Microwave Hydro-Distillation Essential Oil from Fructus Forsythia, Chemical Constituents, and Its Antimicrobial and Antioxidant Activities. Journal of Food Chemistry, 134, 235-243.

Kardinan, A. (2005) : Tanaman Penghasil Minyak Atsiri, Agromedia Pustaka, Jakarta.

Khanuja, P.S., Pawar, A., Darokar, M.P., Rajkumar,S., Sundaresan V., Kumar, S., dan Lal, N. (2005) : Essential Oil Constituents and RAPD Markersto Establish Species Relationship in Cymbopogon Spreng. (Poaceae), Journal of Biochemical Systematics and Ecology, 33, 171-186.

Ketaren, S. (1985) : Pengantar Teknologi Minyak Atsiri, Balai Pustaka, Jakarta.

Lavania, U.C., Basu, S., Lavania, S. (2008) : Towards Bio-Efficient and

Non-Invasive Vetiver : Lessons From Genomic Manipulation And Chromosomal Characterization. http://www.vetiver.org/ICV4pdfs /EB02.pdf.

Lutony, T. L., dan Rahmayati, Y. (2002) : Produksi dan Perdagangan Minyak Atsiri, Penerbit Penebar Swadaya, Jakarta.

Maffei, M. (2002) : Introduction to The Genus Vetiveria, Taylor and Francis, London, 119.

Martinez, J., Paulo, T.V.R., Chantal, M., Alain, L., Pierre, B., Dominique P., dan Angela, A.M. (2004) : Valorization of Brazilian Vetiver (Vetiveria zizanioides L.) Nash ex Small) oil, Journal of Agriculture and Food Chemistry, 53, 6578-6584.

Massardo, D. R., Senatore, F., Alifano, P., Del, L., dan Pontieri, P. (2006) : Vetiver Oil Production Correlates with Early Root Growth, Journal of Biochemical Systematics and Ecology, 34, 376-382. 